\title{
PELATIHAN KEPEMIMPINAN TRANSFORMASIONAL PADA ATASAN UNTUK PENINGKATAN KOMITMEN ORGANISASI KARYAWAN DI HOTEL “X” YOGYAKARTA
}

\author{
Ros Patriani Dewi ${ }^{1}$ dan Kamsih Astuti2 \\ ${ }^{12}$ Fakultas Psikologi, Universitas Mercu Buana Yogyakarta \\ yosie.patriani@gmail.com ${ }^{1}$ \\ tutik.umby@gmail.com²
}

\begin{abstract}
Abstrak
Penelitian ini bertujuan untuk mengetahui pengaruh pelatihan kepemimpinan transformasional pada atasan untuk peningkatan komitmen organisasi karyawan di hotel X Yogyakarta. Subjek penelitian adalah 34 karyawan Hotel X Yogyakarta yang merupakan subordinat atau bawahan sedangkan yang diberikan intervensi berupa pelatihan kepemimpinan transformasional adalah para Head of Departement (HOD) yang berjumlah 8 orang. Metode pengumpulan data yang digunakan adalah skala komitmen organisasi yang mengacu pada organizational commitment questionnaire (OCQ) yang dikembangkan oleh Allen \& Meyer (1990), yang terdiri dari tiga komponen yaitu: komponen afektif, komponen kontinuans dan komponen normatif. Desain eksperimen yang digunakan dalam penelitian ini adalah one group pretest-posttest design dengan analisis data uji statistik parametrik, yaitu Paired Sample T-Test. Hasil penelitian menunjukkan bahwa t = 7,325, $(\mathrm{p}<0,001)$ sehingga hipotesis penelitian diterima. Artinya, ada perbedaan yang signifikan antara komitmen organisasi karyawan sebelum diberikan pelatihan kepemimpinan transformasional pada atasan dan setelah diberikan pelatihan kepemimpinan transformasional pada atasan.
\end{abstract}

Kata Kunci : Pelatihan Kepemimpinan Transformasional, Komitmen Organisasi

\section{TRANSFORMATIONAL LEADERSHIP TRAINING ON SUPERIOR FOR ENHANCEMENT OF EMPLOYEE ORGANIZATION COMMITMENT IN HOTEL "X" YOGYAKARTA}

\author{
Ros Patriani Dewi ${ }^{1}$ dan Kamsih Astuti2 \\ ${ }^{12}$ Faculty of Psychology, University of Mercu Buana Yogyakarta \\ yosie.patriani@gmail.com ${ }^{1}$ \\ tutik.umby@gmail.com²
}

\begin{abstract}
This study aims to determine the effect of transformational leadership training on the employer to increase employee organizational commitment in the hotel X Yogyakarta. The subjects of the study were 34 employees of Hotel X Yogyakarta who are the subordinate, while the intervention of transformational leadership training was the Head of Department (HOD) which amount 8 people. Data collection method used is the scale of organizational commitment that refers to organizational commitment questionnaire (OCQ) developed by Allen \& Meyer (1990), which consists of three components, namely: affective components, continuous components and normative components. The experimental design used in this research was one group pretest-posttest design with parametric statistical test data analysis, namely Paired Sample T-Test. The results show that $t=7,325,(p<0.001)$ so that the research hypothesis is accepted. It means that there is a significant difference between an employee's organizational commitment before given transformational leadership training to superiors and after given transformational leadership training to superiors.
\end{abstract}

Keywords: Transformational Leadership Training, Organizational Commitment 


\section{PENDAHULUAN}

Berkembangnya bisnis pariwisata di wilayah DIY mendorong berkembangnya pula industri di sektor akomodasi, salah satunya ditandai dengan bermunculannya hotel-hotel atau tempat penginapan di DIY. Saat ini, pertumbuhan hotel di wilayah DIY semakin kompetitif. Menurut Ketua PHRI (Perhimpunan Hotel \& Restoran Indonesia), "per Desember 2014, terdapat 104 permohonan izin mendirikan bangunan (IMB) hotel baru. Dari jumlah ini, sebanyak 77 di antaranya telah mendapatkan IMB. Dari 77 IMB yang sudah terbit itu, 36 di antaranya sedang dalam proses pembangunan dan akan beroperasi tahun ini hingga 2016 mendatang," ungkap Ketua PHRI Yogyakarta, Istidjab M Danunagoro kepada www.kompas.com, Senin (2/2/2015). Sedangkan jika dilihat secara general, dari mulai hotel budget, bintang 1 sampai dengan bintang 5, saat ini jumlah hotel di wilayah DIY (yang terdata di PHRI) adalah sebanyak 117 hotel.

Adanya fenomena tersebut menimbulkan dampak tersendiri bagi perusahaan yang bergerak di bidang perhotelan. Salah satunya adalah Hotel X sebagai salah satu hotel bintang tiga di Yogyakarta. Hotel X harus mampu bersaing dengan hotel-hotel lain, terutama yang sekelasnya dan berada di wilayah yang sama. Hotel X merupakan satu-satunya hotel bintang tiga di Yogyakarta yang bukan merupakan chain hotel (hotel group) sehingga tantangan untuk dapat bersaing dengan hotel lain di kelasnya semakin besar. Secara lokasi, Hotel
$\mathrm{X}$ terletak di area yang sangat strategis karena merupakan kawasan wisata utama, yaitu di sekitar Malioboro yang menjadi icon DIY. Walaupun bangunan Hotel X dapat dikatakan modern minimalis namun secara okupansi, Hotel $\mathrm{X}$ dapat bersaing dengan hotel-hotel lain sekelasnya di kawasan yang sama dengan Hotel X. Hal ini terbukti dengan adanya review dari wisatawan yang menginap di Hotel $\mathrm{X}$ dari online travel agent (OTA) seperti: www.booking.com, www.agoda.com, www.tripadvisor.com, dan lain-lain. Hotel X mendapatkan review yang baik dari pengunjung dan juga rating yang memuaskan yaitu diatas 8 poin. Dari hasil review atau penilaian pengunjung, mayoritas menyatakan puas dengan pelayanan dan fasilitas yang diberikan Hotel X. Namun tidak dipungkiri bahwa agar Hotel $\mathrm{X}$ dapat tetap mempertahankan posisinya atau bahkan meningkatkan ke posisi yang lebih tinggi, manajemen Hotel X harus memikirkan strategi yang lebih komprehensif yang mencakup juga pada performance management SDM nya.

Komitmen karyawan sangat penting bagi organisasi yang ingin mempertahankan posisinya atas pemain pasar tenaga kerja yang semakin bergejolak seiring semakin banyak bermunculannya hotel-hotel baru di wilayah DIY. Komitmen karyawan adalah hal yang penting karena berkaitan dengan biaya perekrutan, sosialisasi, dan pelatihan karyawan baru. Individu yang berkomitmen terhadap organisasi akan lebih menunjukkan kinerjanya dan lebih kecil kemungkinannya untuk absen dari pekerjaan, memiliki keinginan yang lebih InSight, Tahun XIII/Nomor 1/Februari 2016 
rendah untuk meninggalkan organisasi, memiliki kepuasan kerja yang meningkat, dan cenderung memiliki peningkatan produktivitas (Allen \& Meyer, 1996; Mathieu \& Zajac, 1990; Meyer \& Allen, 1997). Dengan demikian, komitmen organisasi merupakan syarat penting untuk efektivitas organisasi.

Berdasarkan wawancara awal dengan

HRM (Human Resources \& Development Manager) pada tanggal 05 Mei 2015, diperoleh informasi bahwa turn over karyawan pada tahun 2014 meningkat dibanding tahun sebelumnya, yaitu sebesar 20\%. Karyawan Hotel $\mathrm{X}$ masih tertarik dengan penawaran ataupun kesempatan untuk bekerja di hotel lain dibandingkan untuk tetap bertahan dan mengembangkan karirnya di tempat kerjanya saat ini. Hal ini menunjukkan bahwa komitmen organisasi karyawan Hotel X dapat dikatakan masih rendah. Kenyataan ini menjadikan perhatian khusus pihak manajemen, khususnya pihak HRD yang notabene menangani dan mengelola sumber daya manusia di Hotel X. Dampak negatif dari komitmen organisasi yang masih kurang terhadap Hotel $\mathrm{X}$ sendiri adalah semakin berkurangnya karyawan yang sebelumnya sudah dianggap cukup baik kinerjanya. Selain itu, pihak HRD juga harus mencari lagi kandidat karyawan untuk mengisi posisi yang ditinggalkan oleh karyawan yang resign dan ini bukan pekerjaan yang mudah. SDM memainkan peran strategis untuk memenangkan persaingan. Oleh karena itu, hotel yang dapat merekrut karyawan yang terbaik dan membuatnya tetap berkomitmen terhadap perusahaan akan dapat menjadi pemenang.

Komitmen organisasi merupakan salah satu konsep penelitian yang paling luas dalam literatur perilaku organisasi (Meyer dan Herscovitch, 2001). Bateman dan Strasser (1984) mendefinisikan komitmen organisasi secara multidimensi, mencakup loyalitas karyawan terhadap organisasi, keinginan untuk memberikan upaya sebagai bagian dari organisasi, tingkat kesesuaian antara tujuan dan nilai-nilai organisasi dengan tujuan dan nilai-nilai individu, serta hasrat untuk mempertahankan keanggotaan di dalam organisasi.

$$
\text { Baron dan Greenberg }
$$
menyatakan bahwa komitmen memiliki arti penerimaan yang kuat pada individu terhadap tujuan dan nilai-nilai perusahaan, dimana individu akan berusaha dan berkarya serta memiliki hasrat yang kuat untuk tetap bertahan di perusahaan tersebut. Definisi komitmen organisasi menurut Hall, Schneider, dan Nygren (1970 dalam Suseno dan Sugiyanto, 2010) merupakan proses agar tujuan organisasi dan tujuan individu lebih terintegrasi dan kongruen. Menurut Allen dan Meyer (1990), komitmen organisasi merupakan kondisi psikologis yang menunjukkan karakteristik hubungan antara pekerja dengan organisasi dan mempunyai pengaruh dalam keputusan untuk tetap melanjutkan keanggotaannya di dalam organisasi tersebut. Meyer dan Allen (1997) juga menyatakan bahwa karyawan yang memiliki komitmen organisasi akan bekerja dengan penuh dedikasi karena 
karyawan yang memiliki komitmen tinggi menganggap bahwa hal yang penting yang harus dicapai adalah pencapaian tugas dalam organisasi. Karyawan yang memiliki komitmen organisasi yang tinggi juga memiliki pandangan yang positif dan akan melakukan yang terbaik untuk kepentingan organisasi. Hal ini membuat karyawan memiliki keinginan untuk memberikan tenaga dan tanggung jawab yang lebih menyokong kesejahteraan dan keberhasilan organisasi tempatnya bekerja.

Berdasarkan berbagai definisi mengenai komitmen terhadap organisasi di atas, peneliti menggunakan definisi komitmen organisasi dari Allen dan Meyer (1990) yang menyatakan bahwa komitmen organisasi merupakan kondisi psikologis yang menunjukkan karakteristik hubungan antara pekerja dengan organisasi dan mempunyai pengaruh dalam keputusan untuk tetap melanjutkan keanggotaannya di dalam organisasi tersebut.

Menurut Allen dan Meyer (1990) terdapat tiga komponen dalam komitmen organisasi, yaitu:

\section{a. Komponen affective}

Komponen ini menunjukkan kelekatan emosional pekerja, mengidentifikasikan dirinya dan menunjukkan keterlibatannya di dalam organisasi tersebut. Dimana pekerja yang memiliki komponen afektif yang tinggi melanjutkan keanggotaannya ke dalam organiasi karena memang hal itulah yang mereka inginkan untuk tetap berada di organisasi.

b. Komponen continuance
Komponen ini menunjukkan kesadaran tentang kerugian yang dihadapi seorang pekerja bila dia meninggalkan pekerjaannya. Pekerja yang mau tetap berada di organisasi berdasar komponen continuance karena memang mereka membutuhkan organisasi.

\section{c. Komponen normative}

Komponen ini mencerminkan perasaan tentang kewajiban untuk tetap bekerja di organisasi. Pekerja dengan komponen normatif yang tinggi merasa mereka harus tetap berada di organisasi.

Komitmen organisasi merupakan salah satu fokus yang menarik untuk dibahas dalam bidang Psikologi Industri dan Organisasi. Hal ini disebabkan dengan semakin berkembangnya komitmen organisasi pada diri seorang karyawan, akan mampu mengurangi gejala kerja negatif yang muncul pada organisasi, seperti pemogokan kerja karyawan, demonstrasi karyawan, angka bolos kerja, rasa tidak bergairah dalam bekerja dan turn over. Gejala-gejala kerja yang tidak baik tersebut, bila dibiarkan dapat berpotensi menimbulkan kerugian bagi perusahaan, terutama bila terjadi pada karyawan yang telah dididik dan berpengalaman (Oktorita, Rosyid \& Lestari, 2001).

Beberapa hasil penelitian menunjukkan bahwa salah satu faktor yang dianggap penting yang mempengaruhi komitmen organisasi adalah kepemimpinan (Mowday et al., dalam Avolio et al., 2004). Sebagai bagian dari organisasi, kepemimpinan ikut mempengaruhi komitmen melalui hubungan antara atasan dengan bawahan atau antara karyawan dengan 
pemimpinnya (Meyer \& Allen, 1997). Kepemimpinan berpengaruh kuat terhadap jalannya organisasi dan kelangsungan hidup organisasi. Keberhasilan sebuah organisasi dapat tercapai apabila pemimpin dapat mempengaruhi bawahannya untuk memberikan kinerja terbaik kepada organisasi. Menurut House et. al., (1999) dalam Yukl (2010), kepemimpinan merupakan kemampuan seseorang untuk mempengaruhi, memotivasi, dan membuat orang lain mampu memberikan kontribusinya demi efektivitas dan keberhasilan organisasi.

Mannheim dan Halamish (2008) mengemukakan bahwa di antara tiga gaya kepemimpinan yang hirarkis terstruktur dari Bass dan Avolio, pemimpin yang optimal adalah orang yang menunjukkan sebagian besar gaya transformasional, sedangkan gaya transaksional dan gaya pasif-menghindari (avoiding styles) pada tingkat yang lebih rendah dalam hal gaya kepemimpinan. Ismail et al. (2011) menyatakan bahwa pada era persaingan global, banyak organisasi menggeser paradigma gaya kepemimpinan mereka dari kepemimpinan transaksional ke kepemimpinan transformasional sebagai cara untuk mencapai strategi dan tujuan. Gaya kepemimpinan transformasional sesuai dengan lingkungan organisasi yang dinamis (Ismail et al., 2011). Kepemimpinan transformasional dianggap efektif dalam situasi atau budaya apa pun (Yukl, 2010). Dalam memelihara komitmen organisasi, peran seorang pemimpin yang sangat dibutuhkan adalah pemimpin yang transformasional.

Kepemimpinan transformasional merupakan suatu keadaan dimana seorang pemimpin memiliki karisma atau pengaruh. Pemimpin mempunyai visi dan menggunakannya untuk mentransformasikan anggota organisasi, dalam hal ini anggotanya terinspirasi, percaya dan yakin pada kepentingan dan nilai-nilai dalam pekerjaannya untuk mencapai tujuan bersama. Kepemimpinan transformasional terbagi ke dalam empat dimensi, yaitu: idealized influence, inspirational motivation, intellectual stimulation, dan individual consideration (Bass \& Avolio, 1993).

Berdasarkan hasil wawancara dan observasi yang menggunakan metode $7 \mathrm{~S}$ McKinsey pada awal penelitian yang dilakukan kepada pihak Head of Department, Supervisor, dan Staff, diperoleh kesimpulan bahwa aspek Style atau Gaya Kepemimpinan termasuk ke dalam aspek yang rendah atau perlu mendapat perhatian di Hotel X. Para karyawan di level Supervisor dan Manajer masih belum sepenuhnya memiliki fungsi kepemimpinan yang efektif sehingga hal ini diyakini oleh pihak HRM juga sebagai salah satu penyebab meningkatnya turn over di Hotel X karena dari hasil penelusuran HRM, beberapa karyawan yang mengundurkan diri dari Hotel $\mathrm{X}$ menyatakan bahwa fungsi kepemimpinan para Head of Departement (HOD) masih belum efektif. Karyawan merasa kurang puas dan kurang dihargai oleh atasan. Hubungan antara atasan dengan bawahan juga masih kurang baik dan terkesan berjarak. Komunikasi dua arah masih kurang berjalan dengan lancar. Adanya fenomena ini secara 
langsung atapun tidak langsung mempengaruhi komitmen karyawan terhadap organisasi.

Hasil wawancara menunjukkan bahwa Head of Department (HOD) atau pimpinan departemen di Hotel X masih belum dapat menjalankan tugas dan fungsi kepemimpinannya secara efektif. Menurut HRD Manager, HOD di Hotel X masih belum dapat menunjukkan gaya kepemimpinan yang dapat merangkul bawahannya, belum mampu menjadi "leader" yang baik, dan belum dapat menjalin hubungan yang efektif dengan bawahannya. Menurut salah satu HOD sendiri, yaitu Front Office Manager (FOM), yang bersangkutan masih merasa kesulitan untuk melakukan pengarahan kepada bawahannya dan juga masih belum dapat menjadi pemimpin yang berkharisma. Di samping itu, menurut salah satu bawahan yang diwawancarai, yaitu Housekeeping Attendant, sosok pemimpin (HOD) di departemen nya sebagian karakter pemimpin yang baik sudah ditunjukkan oleh yang bersangkutan, namun masih ada beberapa karakter lain yang dimiliki oleh HOD yang masih dianggap kurang transformasional, yaitu pemimpin belum dapat memotivasi dan juga menginspirasi bawahannya.

Hasil wawancara tersebut juga didukung hasil observasi yang dilakukan terhadap kepemimpinan HOD di hotel X. Hasil observasi memperlihatkan bahwa HOD masih belum sepenuhnya mampu berperilaku sebagai pemimpin yang memiliki karakteristik pemimpin transformasional. Data observasi yang dilakukan pada tanggal 7- 15 Juli 2014 menunjukkan bahwa para pemimpin (HOD) di
Hotel X masih be/lum menjadi agent of change dan belum dapat menjadi pemimpin yang mampu memberdayakan bawahannya. Pimpinan departemen di hotel $\mathrm{X}$ masih belum mampu memberikan pengaruh yang ideal kepada bawahannya, belum mampu menjadi motivator sekaligus inspirator bagi bawahan dalam bekerja. Pimpinan masih belum dapat merangsang potensi bawahannya untuk menampilkan performa terbaiknya sehingga bawahan kurang termotivasi untuk memiliki komitmen yang tinggi terhadap organisasi.

$$
\text { Peran atasan dalam mengayomi }
$$
karyawan untuk mencapai target yang telah ditetapkan perusahaan semakin dinilai penting sehingga perusahaan perlu menyiapkan pemimpin-pemimpin yang kompeten di tiap lini organisasi. Atasan berperan dalam menciptakan suasana kerja yang kondusif bagi karyawannya. Pemimpin transformasional mempengaruhi bawahan untuk tingkat yang lebih tinggi pada komitmen dan kinerja dengan mengartikulasi visi, mendorong penerimaan tujuan kelompok dan mengembangkan anggota kelompok individu untuk mencapai potensi tertinggi mereka (Podsakoff, MacKenzie, \& Bommer, 1996). Bass (1990) menjelaskan kepemimpinan transformasional merupakan perilaku pemimpin yang menstimulasi dan menginspirasi bawahannya untuk meraih prestasi yang luar biasa dan memelihara level komitmen dan moral antara pemimpin tersebut dan bawahannya. Tipe pemimpin transformasional cenderung melibatkan para karyawan atau bawahan dalam mengelola kinerja organisasi, sehingga bawahan dianggap sebagai mitra kerja yang InSight, Tahun XIII/Nomor 1/Februari 2016 
sejajar dan saling membutuhkan (Piccolo, 2004).

Peningkatan kepemimpinan transformasional dapat dilakukan dengan beberapa cara, misalnya dengan memberikan pelatihan dan umpan balik kepemimpinan transformasional, memberikan konseling dengan memberikan umpan balik (Barling, et al, 2010, dalam Syafiq, 2012), serta memberikan serangkaian program pengembangan kepemimpinan yang terdiri dari pelatihan-umpan balik-personal plandiskusi kelompok (Avolio \& Bass, 1998, dalam Syafiq, 2012).

Pelatihan

kepemimpinan transformasional adalah metode intervensi yang diberikan kepada pimpinan yang bertujuan agar pimpinan mampu menjadi panutan bagi bawahannya, mampu menjadi sumber inspirasi bagi bawahannya, dapat membantu bawahannya untuk melihat dunia dengan sudut pandang yang berbeda dan mampu mendiagnosa, memenuhi, dan meningkatkan kebutuhan setiap karyawannya sehingga membantu bawahan mengatasi setiap permasalahan yang ada.

Berdasarkan uraian permasalahan di atas, usaha peningkatan komitmen organisasi dapat dilakukan dengan memberikan pelatihan kepemimpinan transformasional. Salah satu penelitian yang dilakukan oleh Tarmizi (2008) membuktikan bahwa pelatihan kepemimpinan transformasional dapat meningkatkan komitmen organisasi dan kepuasan kerja karyawan. Hasil penelitian menunjukkan adanya peningkatan komitmen organisasi dan kepuasan kerja karyawan pada kelompok eksperimen setelah atasan mereka diberikan pelatihan kepemimpinan transformasional dibandingkan dengan kelompok kontrol.

Beberapa penelitian membuktikan bahwa kepemimpinan transformasional berpengaruh terhadap peningkatkan komitmen organisasi pada karyawan (Gao \& Bai, 2011; Avolio, 2004; Nurafiah, 2009; Rizadinata, 2013; Rahmi, 2013). Selain itu, Bass dalam bukunya "Leadership and performance beyond expectations" (1985) menyatakan bahwa kepemimpinan transformasional akan mendorong bawahan mereka untuk berpikir secara kritis dan mampu melihat cara-cara baru sehingga mereka memiliki kemampuan memecahkan masalah dengan metode yang baru. Situasi ini akan memotivasi bawahan dan membuat mereka lebih fokus terhadap pekerjaannya, sehingga pada akhirnya akan terbentuk kepuasan kerja dan komitmen organisasi. Shamir dan koleganya (Shamir, House, \& Arthur, 1993) menambahkan pemimpin transformasional dapat mempengaruhi komitmen bawahan dalam tiga cara yaitu; pertama, memastikan bahwa tingkatan tinggi pada nilai organisasi telah diadopsi; kedua, menekankan hubungan antara usaha bawahan dan pencapaian tujuan; ketiga, menciptakan lingkungan yang menekankan pada visi dan tujuan organisasi. Penelitian eksperimental mengenai pengaruh pelatihan kepemimpinan transformasional terhadap komitmen organsisasi belum banyak dilakukan, oleh karena itu peneliti tertarik untuk melakukan penelitian eksperimental 
dengan cara memberikan metode intervensi berupa pelatihan kepemimpinan transformasional yang akan berdampak pada peningkatan komitmen organisasi karyawan. Adapun hipotesis dalam penelitian ini adalah ada perbedaan tingkat komitmen organisasi karyawan sebelum pelatihan kepemimpinan transformasional pada atasan dan setelah pelatihan kepemimpinan transformasional pada atasan dimana skor komitmen organisasi karyawan lebih tinggi setelah adanya pemberian intervensi pelatihan kepemimpinan transformasional pada atasan.

\section{METODE}

Penelitian ini menggunakan komitmen organisasi sebagai variabel dependen dan pelatihan kepemimpinan transformasional sebagai variabel independen. Komitmen organisasi merupakan kondisi psikologis yang menunjukkan karakteristik hubungan antara pekerja dengan organisasi dan mempunyai pengaruh dalam keputusan untuk tetap melanjutkan keanggotaannya di dalam organisasi tersebut. Definisi tersebut diambil dari Allen dan Meyer (1990). Aspek-aspek komitmen organisasi menurut Allen dan Meyer (1990) adalah: komponen afektif, komponen kontinuans, dan komponen normatif. Pelatihan kepemimpinan transformasional adalah metode intervensi yang diberikan kepada pimpinan yang bertujuan agar pimpinan mampu menjadi panutan bagi bawahannya, mampu menjadi sumber inspirasi bagi bawahannya, dapat membantu bawahannya untuk melihat dunia dengan sudut pandang yang berbeda dan mampu mendiagnosa, memenuhi, dan meningkatkan kebutuhan setiap karyawannya sehingga membantu bawahan mengatasi setiap permasalahan yang ada. Pelatihan kepemimpinan transformasional terdiri dari tiga babak, yaitu: babak awal, babak tengah, dan babak akhir. Sesi-sesi dalam pelatihan ini mengacu pada aspek-aspek atau dimensi dari kepemimpinan transformasional menurut Bass dan Avolio (1993), yaitu: Idealized Influence (Pengaruh Ideal), Inspirational Motivaton (Motivasi Inspirasional), Intellectual Stimulation (Stimulasi Intelektual), dan Individual Consideration (Perhatian Individual).

Desain penelitian yang digunakan adalah One Group Pretest-Posttest Design, yaitu sebuah desain penelitian yang pada awalnya satu kelompok eksperimen diukur variabel dependennya (pretest). Setelah itu kelompok tersebut diberikan perlakuan, dan diukur kembali variabel dependennya (posttest).

Penelitian ini dilakukan di perusahaan yang bergerak dalam bidang industri perhotelan di Yogyakarta, yaitu hotel $\mathrm{X}$ yang memiliki bisnis inti, yakni: room service, restaurant service, dan meeting room service serta memiliki klasifikasi hotel bintang tiga. Subjek penelitian adalah karyawan yang menjadi subordinat atau bawahan dari HOD (Head of Department) yang diberikan intervensi pelatihan kepemimpinan transformasional yang berjumlah 34 orang, meliputi supervisor dan staff. Kriteria sbujek dalam penelitian ini, yaitu memiliki masa kerja minimal 1 (satu) tahun dan minimal 6 (enam) 
bulan telah bekerja di bawah supervisi HOD. Adapun manipulasi variabel bebas yang diberikan pada penelitian ini adalah berupa pelatihan kepemimpinan transformasional pada atasan (Head of Departement) yang berjumlah 8 (delapan) orang. Kriteria peserta pelatihan ini yaitu memiliki masa kerja minimal 1 (satu) tahun sebagai HOD dan memiliki minimal satu orang subordinat langsung sebagai subjek penelitian.

Metode pengumpulan data yang digunakan oleh peneliti dalam penelitian ini adalah dengan menggunakan skala yang berisi pernyataan-pernyataan yang berkaitan dengan komitmen organisasi dan wawancara. Skala Komitmen Organisasi mengacu pada Organizational Commitment Questionaire yang disusun oleh Allen dan Meyer (1990) dan sudah dimodifikasi oleh peneliti, yang terdiri atas tiga aspek, yaitu: komitmen afektif, komitmen kontinuans, dan komitmen normatif. Hasil uji validitas dan reliabilitas dari Skala Komitmen Organisasi yaitu $\alpha=0,936$ dan $\mathrm{r}=$ $0,351-0,757(\mathrm{r}>0,30)$.

Teknik analisis data yang digunakan dalam penelitian ini adalah uji statistik parametrik dengan menggunakan teknik analisis paired sample t-test yang bertujuan untuk menguji perbedaan di antara dua kelompok data yang berhubungan (berasal dari subjek yang sama).

\section{HASIL DAN PEMBAHASAN}

Berdasarkan perhitungan statistik deskriptif diperoleh rerata pretest sebesar 71,71 dan rerata posttest sebesar 79,21. Dapat diartikan bahwa sebelum dan sesudah pemberian pelatihan kepemimpinan transformasional pada atasan terjadi peningkatan komitmen organisasi karyawan. Adapun deskripsi data Komitmen Organisasi dapat dilihat pada Tabel 1.

Berdasarkan hasil kategorisasi data penelitian, dapat disimpulkan ada peningkatan skor komitmen organisasi karyawan antara pretest dan posttest. Pada skor pretest, didapatkan kategori Tinggi berjumlah 6 orang, kategori Sedang berjumlah 22 orang, sedangkan yang ada di kategori Rendah ada 6 orang. Sementara pada skor posttest, didapatkan kategori Tinggi 12 orang dan kategori Sedang 24. Data ini memperlihatkan bahwa komitmen organisasi karyawan mengalami peningkatan pada saat posttest atau setelah atasan mereka diberikan pelatihan kepemimpinan transformasional.

Tabel 1. Deskripsi Data Komitmen Organisasi

\begin{tabular}{ccc}
\hline $\begin{array}{c}\text { Komitmen } \\
\text { Organisasi }\end{array}$ & $\begin{array}{c}\text { Pretest } \\
(\mathbf{n}=\mathbf{3 4})\end{array}$ & $\begin{array}{c}\text { Posttest } \\
(\mathbf{n}=\mathbf{3 4})\end{array}$ \\
\hline Min & 51 & 63 \\
Maks & 88 & 98 \\
Rerata & 71.21 & 79.21. \\
SD & 9,463 & 7,210 \\
\hline
\end{tabular}


Berdasarkan hasil analisis yang dilakukan, dapat diketahui nilai minimum, maksimum, rata-rata, dan standar deviasi dari tiga aspek komitmen organisasi, yaitu: komponen afektif, komponen kontinuans, dan komponen normatif, seperti pada Tabel 2 .

Tabel 2. Deskripsi Pretest dan Posttest Komitmen Organisasi Berdasarkan Aspeknya

\begin{tabular}{|c|c|c|c|c|c|c|}
\hline \multicolumn{7}{|c|}{ Retest } \\
\hline Aspek & $\mathrm{N}$ & Min & Max & Sum & Mean & SD \\
\hline Afektif & 34 & 18 & 32 & 856 & 25.18 & 3.588 \\
\hline Kontinunans & 34 & 16 & 31 & 810 & 23.82 & 3.546 \\
\hline Normatif & 34 & 16 & 29 & 772 & 22.71 & 3.597 \\
\hline \multicolumn{7}{|c|}{ Posttest } \\
\hline Aspek & $\mathrm{N}$ & Min & $\operatorname{Max}$ & Sum & Mean & $\mathrm{SD}$ \\
\hline$\overline{\text { Afektif }}$ & 34 & 22 & 34 & 982 & 28.88 & 3.245 \\
\hline Kontinunans & 34 & 21 & 32 & 861 & 25.32 & 2.879 \\
\hline Normatif & 34 & 17 & 32 & 850 & 25.00 & 3.601 \\
\hline
\end{tabular}

Berdasarkan data tersebut, dapat dilihat komitmen organisasi saat pretest dan posttest mengalami peningkatan, seperti pada gambar 1 .

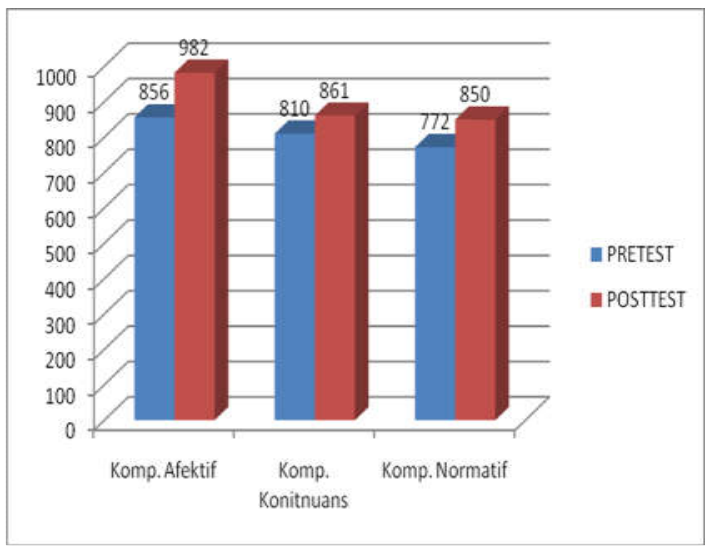

Gambar 1. Grafik Komitmen Organisasi berdasarkan aspek saat pretest dan posttest

Berdasarkan kategorisasi skor paling tinggi adalah komponen afektif, komitmen organisasi dengan melihat dari

$$
\text { masing-masing aspek (afektif, }
$$
kemudian yang tertinggi kedua adalah kontinuans, dan normatif) pada saat pretest dan posttest, dapat disimpulkan bahwa aspek atau komponen komitmen organisasi yang komponen kontinuans, sedangkan komponen normatif berada di peringkat ketiga atau paling rendah. Hal ini menunjukkan bahwa responden penelitian dalam hal ini subordinat/bawahan 
dari subjek penelitian yang diberikan pelatihan, memiliki komitmen afektif yang lebih tinggi dibandingkan komponen komitmen organisasi lainnya, yaitu komponen kontinuans dan komponen normatif dan masing-masing komponen mengalami peningkatan dari pretest ke posttest.

Uji hipotesis bertujuan untuk mengetahui apakah ada perbedaan tingkat komitmen organisasi karyawan setelah adanya pelatihan kepemimpinan transformasional pada atasan. Uji hipotesis dilakukan dengan menggunakan Paired Sample T Test yaitu untuk menguji perbedaan diantara dua kelompok data yang berhubungan (berasal dari subjek yang sama). Hasil dari Paired Sample T Test, diperoleh nilai $\mathrm{t}=8,072,(\mathrm{p}<0,01)$, yang berarti terdapat perbedaan skor komitmen organisasi antara pretest dan posttest, dimana skor posttest lebih besar daripada skor pretest. Hal ini menunjukkan bahwa pelatihan kepemimpinan transformasional yang diberikan pada atasan berpengaruh terhadap peningkatan komitmen organisasi karyawan di Hotel X Yogyakarta.

Evaluasi perilaku yang dilakukan melalui pemberian training assignment selama 10 hari kerja menunjukkan bahwa para atasan mampu mengembangkan aspek kepemimpinan transformasional yang masih menjadi kelemahan mereka dengan cara mempraktekkan aspek-aspek kepemimpinan transformasional, yaitu pada aspek Idealized Influence, Inspirational Motivation, Intellectual Stimulation, dan Individual
Consideration. Berdasarkan wawancara dengan salah satu bawahan dari masingmasing HOD, hasil menyimpulkan bahwa semua HOD telah menunjukkan perubahan gaya kepemimpinan yang lebih baik dari sebelumnya. Bawahan merasakan perubahan yang positif dari perilaku atasan setelah mereka diberi pelatihan kepemimpinan transformasional. Hubungan antara atasan dengan bawahan juga lebih akrab dan terbuka. Karyawan merasa lebih diperhatikan oleh atasan mereka, lebih termotivasi untuk meningkatkan kinerja mereka dan lebih mencintai pekerjaan mereka, serta merasa nyaman dengan atasan mereka sehingga karyawan akan lebih berkomitmen terhadap organisasi.

Berdasarkan hasil analisis data dapat disimpulkan bahwa hipotesis penelitian diterima. Dengan demikian, ada perbedaan tingkat komitmen organisasi karyawan sebelum dan setelah pelatihan kepemimpinan transformasional pada atasan dengan skor komitmen organisasi karyawan lebih tinggi setelah adanya pemberian intervensi pelatihan kepemimpinan transformasional pada atasan.

Pelatihan yang diberikan kepada atasan (HOD) di Hotel X Yogyakarta bertujuan untuk meningkatkan kemampuan atasan agar mereka mampu menjadi panutan bagi bawahannya, mampu menjadi sumber inspirasi bagi bawahannya, dapat membantu bawahannya untuk melihat dunia dengan sudut pandang yang berbeda dan mampu mendiagnosa, memenuhi, dan meningkatkan kebutuhan 
setiap karyawannya sehingga membantu bawahan mengatasi setiap permasalahan yang ada. Sesi-sesi dalam pelatihan kepemimpinan transformasional ini mengacu pada aspekaspek atau dimensi dari kepemimpinan transformasional menurut Bass dan Avolio (1993), yaitu: Idealized Influence (Pengaruh Ideal), Inspirational Motivaton (Motivasi Inspirasional), Intellectual Stimulation (Stimulasi Intelektual), dan Individual Consideration (Perhatian Individual). Peningkatan kualitas kepemimpinan transformasional melalui pelatihan kepemimpinan transformasional dilakukan dengan cara memberikan materi dan penugasan selama pelatihan maupun rencana tindakan (action plan) di tempat kerja. Subjek pelatihan mendapatkan kesempatan untuk menerapkan ketrampilan yang diperoleh selama mengikuti pelatihan kepemimpinan transformasional selama dua minggu atau sepuluh hari kerja setelah pelatihan diberikan. Atasan yang telah mengikuti pelatihan kepemimpinan transformasional diharapkan dapat membantu karyawan ke dalam suatu perubahan cara berpikir, pengembangan visi, pengertian dan pemahaman tentang tujuan organisasi. Kepemimpinan transformasional juga mampu membawa perubahan secara terus menerus dengan pengolahan aktivitas kerja yang memanfaatkan bakat, keahlian, kemampuan ide dan pengalaman sehingga karyawan merasa terlibat dan bertanggung jawab dalam menyelesaikan pekerjaan. Bass dan Avolio (1993) mengemukakan bahwa kepemimpinan transformasional sebagai pengaruh pemimpin atau atasan terhadap bawahan. Para bawahan merasakan adanya kepercayaan, kebanggaan, loyalitas, dan rasa hormat kepada atasan, dan mereka termotivasi untuk melakukannya melebihi apa yang diharapkan. Kepemimpinan transformasional harus dapat mengartikan dengan jelas mengenai sebuah visi organisasi sehingga para pengikutnya akan menerima kredibilitas pemimpin tersebut ( $\mathrm{Su}$ Fun $\mathrm{Yu}, 2000$; dalam Syafiq, 2012). Metode pelatihan dalam penelitian ini menggunakan metode experiential learning yang digunakan untuk memfasilitasi belajar orang dewasa. Experiential learning adalah proses belajar yang terjadi ketika subjek melakukan suatu aktivitas, kemudian memperhatikan, menganalisis aktivitas yang dilakukannya itu secara kritis, lalu mencari insight atau pemahaman yang berguna dari analisis yang dilakukan dan menetapkan insight tersebut dalam perilaku mendatang.

Sesi terakhir pada pelatihan kepemimpinan transformasional adalah penyusunan action plan untuk mendiskusikan training assignment. Pada sesi ini, peserta diminta membuat rencana tindakan demi suksesnya penerapan kepemimpinan transformasional, yang dilakukan dengan mengidentifikasi potensi diri (kekuatan dan kelemahan), mengidentifikasi rencana tindakan dalam kurun waktu berdasarkan skala prioritas dan memonitor realisasi tindakan. Sesi ini diberikan agar peserta mampu mengimplementasikan konsep-konsep kepemimpinan transformasional dalam bidang pekerjaan masing-masing dan peserta mampu InSight, Tahun XIII/Nomor 1/Februari 2016 
membuat perencanaan di dalam menerapkan metode kepemimpinan transformasional.

Intervensi pelatihan kepemimpinan transformasional yang diberikan kepada para atasan yaitu Head of Departement (HOD) di Hotel X Yogyakarta dengan tujuan agar para atasan/pimpinan dapat mengembangkan kompetensi kepemimpinan mereka melalui aspek-aspek kepemimpinan transformasional terbukti secara signifikan meningkatkan komitmen organisasi karyawan seiring dengan adanya praktek-praktek kepemimpinan transformasional yang diterapkan atasan di tempat kerja setelah adanya pelatihan kepemimpinan transformasional. Berdasarkan hasil evaluasi pengetahuan terdapat peningkatan skor antara pretest dan posstest (nilai mean sebelum pelatihan sebesar 3,875 dan sesudah pelatihan sebesar 5,625), sehingga dapat disimpulkan bahwa terjadi peningkatan pengetahuan dan pemahaman dari para peserta pelatihan terhadap materi kepemimpinan transformasional. Hal ini menunjukkan bahwa peserta sudah semakin mengetahui dan memahami bagaimana karakteristik atau indikator perilaku yang sesuai dengan aspekaspek kepemimpinan transformasional sehingga dapat menjadi panduan bagi para peserta (HOD) untuk melakukan praktek kepemimpinan transformasional dalam pekerjaannya sehari-hari.

Berdasarkan evaluasi perilaku yang dilakukan melalui pemberian training assignment selama 10 hari kerja, hasilnya menunjukkan bahwa para atasan mampu mengembangkan aspek kepemimpinan transformasional yang masih menjadi kelemahan mereka dengan cara mempraktekkan aspek-aspek kepemimpinan transformasional, yaitu pada aspek Idealized Influence, Inspirational Motivation, Intellectual Stimulation, dan Individual Consideration. Berdasarkan rencana tindakan yang telah dibuat, mereka menyatakan akan mengembangkan kelemahan mereka, seperti: belum dapat menciptakan suasana kerja yang menyenangkan bagi bawahan, belum dapat menumbuhkan kepercayaan bawahan terhadap kemampuan untuk menyelesaikan tugas dalam mencapai tujuan, kurang mampu mendorong bawahan untuk memunculkan ide-ide baru dan solusi kreatif atas pemecahan masalah, memberikan perhatian secara personal pada bawahan, dan lain-lain. Berdasarkan laporan monitoring harian yang mereka isi selama 10 hari kerja, mereka telah melakukan beberapa aktivitas yang mendukung untuk mencapai tujuan mereka tersebut, misalnya: berusaha meyakinkan bawahan bahwa mereka mampu mengerjakan tugasnya dengan cara memotivasi mereka dengan kata-kata yang membangkitkan kepercayaan diri, menanyakan kendala apa yang dialami oleh masing-masing bawahan, merangsang bawahan agar aktif menyampaikan gagasannya dan mendorong bawahan untuk belajar berpikir di luar kebiasaan, memberikan masukan kepada bawahan yang terlihat masih kurang percaya diri dalam menjalankan tugasnya, dan sebagainya. 
Aktivitas-aktivitas tersebut sangat berpengaruh untuk meningkatkan komitmen organisasi karyawan. Atasan yang memiliki gaya kepemimpinan yang transformasional mampu memberikan keteladanan kepada bawahannya melalui perilaku dan ucapan. Perwujudan sikap keteladanan tersebut seperti memberi contoh bagaimana dia berperilaku dalam melayani orang lain, khususnya dalam melayani karyawan sebagai mitra kerja. Atasan mampu memotivasi bawahannya untuk selalu mempertanyakan asumsi di balik suatu hal, mencari cara baru dalam mengerjakan sesuatu. Ia lebih berfokus pada pemberian apresiasi pada setiap gagasan, sekecil apapun gagasan tersebut sehingga hal ini membuat karyawan bergairah untuk mengemukakan gagasannya. Atasan mampu memberikan perhatian pada bawahannya secara personal, menghargai perbedaan setiap individu serta memberi nasihat dan penghargaan. Ia memperlakukan pengikutnya dengan penuh rasa hormat sesuai dengan keunikan masingmasing bawahan.

Berdasarkan wawancara dengan salah satu bawahan dari masing-masing HOD, dapat disimpulkan bahwa semua HOD telah menunjukkan perubahan gaya kepemimpinan yang lebih baik dari sebelumnya. Bawahan merasakan perubahan yang positif dari perilaku atasan pada akhir-akhir ini walaupun bawahan tidak mengetahui jika atasan mereka diberi pelatihan kepemimpinan transformasional. Hubungan antara atasan dengan bawahan juga menjadi lebih akrab dan terbuka. Karyawan merasa lebih diperhatikan oleh atasan mereka, lebih termotivasi untuk meningkatkan kinerja mereka, lebih betah bekerja di kantor, dan merasa nyaman dengan atasan mereka sehingga karyawan akan lebih merasa terikat dan terlibat terhadap permasalahan organisasi dan hal tersebut berpengaruh terhadap peningkatan komitmen organisasi, khususnya komitmen afektif.

Berdasarkan hasil analisis yang dilakukan terhadap masing-masing komponen komitmen organisasi, yaitu: komponen afektif, komponen kontinuans, dan komponen normatif, diperoleh kesimpulan bahwa dari hasil pretest dan posttest, terdapat peningkatan rerata skor dari masing-masing aspek. Komponen afektif merupakan komponen yang paling tinggi nilainya, kemudian komponen kontinuans, dan yang paling rendah nilainya adalah komponen normatif. Hal ini menunjukkan bahwa pada dasarnya karyawan cenderung merasa terikat pada organisasi dan lebih memilih untuk bertahan dalam organisasi karena adanya kelekatan emosional pada diri karyawan. Adanya peningkatan tingkat komitmen afektif sebelum dan sesudah pelatihan kepemimpinan transformasional pada atasan membuktikan bahwa kepemimpinan atasan berpengaruh siginifikan terhadap komitmen afektif karyawan dan ini menjadi modal yang berharga bagi organisasi. Hasil penelitian ini juga sesuai dengan penelitian Steers dan Porter (1983) yang menemukan salah satu faktor yang mempengaruhi terbentuknya komitmen organisasi, yaitu: hubungan atasan dan bawahan, kualitas hubungan atasan dan bawahan merupakan hasil pembentukan peran yang dilakukan seorang atasan terhadap 
bawahan. Apabila kualitas hubungan baik, seringkali terjadi diskusi tentang penyelesaian permasalahan pekerjaan. Ikatan kerja yang kuat antara atasan dan bawahan dapat menghindarkan dan mengurangi rasa keterasingan di tempat kerja, sehingga berpengaruh pada kekuatan komitmen. Faktor yang kedua adalah sifat dan karakteristik pimpinan serta cara-cara dalam pengambilan keputusan dan kebijakan. Hal ini sangat berpengaruh pada pembentukan komitmen, pimpinan harus mempunyai sifat peduli, mengerti, dan berusaha akomodatif terhadap pendapat bawahannya. Oleh karena itu, dapat disimpulkan bahwa kepemimpinan transformasional mempunyai pengaruh positif terhadap komitmen afektif dan komitmen kontinuans, dimana dengan adanya kualitas hubungan yang positif antara atasan dan bawahan membuat karyawan merasa semakin terikat secara emosional pada organisasi dan merasa rugi jika harus meninggalkan organisasi walaupun kesempatan bekerja di luar semakin banyak.

Adanya pengaruh pelatihan kepemimpinan trasformasional pada atasan terhadap peningkatan komitmen organisasi karyawan sesuai dengan penelitian yang telah dilakukan sebelumnya oleh Tarmizi (2008) dan Barling, dkk (1996). Dalam penelitian Tarmizi, pelatihan kepemimpinan transformasional yang diberikan pada atasan terbukti secara signifikan dapat meningkatkan komitmen organisasi karyawan sedangkan pada karyawan yang atasannya tidak diberikan pelatihan kepemimpinan transformasional tidak menunjukkan adanya perbedaan yang signifikan dalam peningkatan komitmen organisasi.

Barling, dkk (1996) melakukan penelitian field experiment mengenai pengaruh pelatihan kepemimpinan transformasional terhadap sikap dan aspek finansial. Pelatihan kepemimpinan transformasional terbukti dapat meningkatkan persepsi bawahan terhadap kepemimpinan atasan dan komitmen karyawan terhadap organisasi. Hasil penelitian menunjukkan bahwa persepsi karyawan terhadap atasan yang diberikan pelatihan kepemimpinan transformasional meningkat dan juga secara signifikan meningkatkan komitmen organisasi karyawan yang menjadi subordinat dari atasan yang diberikan pelatihan.

Penelitian ini memiliki keterbatasan yaitu dengan tidak adanya kelompok kontrol karena keterbatasan subjek penelitian sehingga efek dari pelatihan kepemimpinan transformasional terhadap komitmen organisasi tidak ada kelompok pembandingnya. Adanya kelompok kontrol atau desain dua-kelompok, maka hasil yang diperoleh lebih meyakinkan bahwa hanya variabel bebas yang mempengaruhi variabel tergantung. Dengan kata lain, validitas internal desain dua-kelompok lebih kuat dibandingkan desain satu-kelompok. Diharapkan pada, peneliti selanjutnya untuk dapat melibatkan kelompok kontrol dalam penelitian yang sejenis dengan penellitian ini. 


\section{KESIMPULAN}

Berdasarkan hasil penelitian dan pembahasan yang telah diuraikan, maka dapat ditarik kesimpulan bahwa pemberian pelatihan kepemimpinan transformasional pada atasan yang disusun peneliti berdasarkan aspek-aspek kepemimpinan transformasional, yaitu: idealized influence (pengaruh ideal), inspirational motivation (motivasi inspirasional), intellectual stimulation (stimulasi intelektual), dan individual consideration (perhatian individual), terbukti berpengaruh pada peningkatan komitmen organisasi karyawan.

Berdasarkan analisis data penelitian yang dilakukan, hasilnya menunjukkan bahwa terjadi peningkatan komitmen organisasi karyawan secara signifikan sebelum dan setelah adanya intervensi pelatihan kepemimpinan transformasional pada atasan. Hal ini berarti pelatihan kepemimpinan transformasional pada atasan merupakan faktor penting dalam meningkatkan serta menumbuhkan komitmen organisasi karyawan yang dibuktikan dengan diterimanya hipotesis dalam penelitian ini.

Hasil evaluasi pengetahuan turut memperkuat terbuktinya hipotesis penelitian ini, dimana terjadi peningkatan pengetahuan dan pemahaman dari para peserta pelatihan terhadap materi kepemimpinan transformasional sehingga mereka dapat lebih memahami karakteristik kepemimpinan transformasional yang dapat diterapkan dalam lingkungan kerja. Selain itu, didukung dari hasil evaluasi perilaku melalui training assignment selama 10 hari kerja dan wawancara dengan salah satu bawahan dari masing-masing HOD, hasilnya menunjukkan bahwa para HOD telah mampu menerapkan aspek-aspek kepemimpinan transformasional di tempat kerja dan bawahan merasakan perubahan yang positif dari perilaku atasan mereka tersebut. Karyawan merasa lebih termotivasi dan bekerja lebih nyaman di bawah gaya kepemimpinan HOD yang lebih transformasional. Karyawan menjadi merasa lebih terikat pada organisasi dibandingkan sebelumnya komitmen organisasi karyawan menjadi lebih meningkat terutama komitmen afektif.

\section{DAFTAR PUSTAKA}

Allen, A.J., \& Meyer, J.P. (1990). The measurement and antecedent of affective continuance, and normative commitment to organization. Journal of Occupational Psychology, 63, 1 - 18.

Allen, A.J., \& Meyer, J.P. (1996). Affective, continuance, and normative commitment to the organization: an examination of construct validity. Journal of Vocational Behavior, 49, 252- 276.

Avolio, B.J, Zhu, W, Koh, W., \& Bhatia, P. (2004), Transformational leadership and organizational commitment: Mediating role of psychological empowerment and moderating role of structural distance. Journal Organization Behavior, 25(8):951-68.

Avolio, B.J., Dvir, T., Eden, D., \& Shamir, B. (2002). Impact of transformational leadership in follower development and performance. A field experiment. Academy of Management Journal, 45, 735-744.

Barling, J., Weber, T., Kelloway, E. K. (1996). "Effects of transformational leadership

InSight, Tahun XIII/Nomor 1/Februari 2016 
training on attitudinal and financial outcomes: A field experiment". Journal of Applied Psychology, Vol 81: 827832.

Baron \& Greenberg. (1990). Behavior in organizations, 3rd ed. Boston, MA: Allyn \& Bacon (A Division of Simon \& Schuster, Inc.).

Bass, B.M. (1985). Leadership and performance beyond expectation. New York: The Free Press.

Bass, B.M. (1990). From transactional to transformational leadership. Learning to share the vision of organizational dynamic. New Jersey: Laurence Eribaum Inc.

Bass, B.M \& Avolio. (1993). Transformational leadership and organizational culture. Public Administration Quarterly.

Bass, B.M., \& Avolio, B.J. (2003). Multifactor leadership questionnaire feedback report. New York: Mind Garden Inc.

Bateman, T.S., \& Strasser, S. (1984). A longitudinal analysis of the antecedents of organizational commitment. Academy of Management Journal , 95-112.

Gao, F.Y., \& Bai, S. (2011). The effects of transformational leadership on organiztional commitment of family employees in chinese family business. International Conference on economics, Trade, and Development, Vol. 7.

Ismail, A., Mohamad, M.H., Mohamed, H.A., Rafiuddin, N.M., \& Zhen, K.W.P. (2011). Transformational and transactional leadership styles as a predictor of individual outcomes. Theoretical and Applied Economics,Vol. 17 No. 6(547), pp. 89 104.

Manheim, B., \& Hila, H. (2008). Transformational leadership as related to team outcome and contextual moderation. Leadership \& Organization
Development

Journal.

Vol.29.No.7.pp.617-630.

Mathieu, J. E. \& Zajac, D. M. (1990). A review and meta analysis of the antecedents, correlates, consequences of organizational commitment, Psychological Bulletin. Vol. 108.

Meyer J.P., \& Allen N.J. (1997). Commitment in the workplace: Theory, research, and application. Thousand Oaks, CA.: Sage Publishing, Inc.

Meyer, J., \& Herscovitch, L. (2001). Commitment in the workplace: Towards a general model. Human Resource Management Review , 299-326.

Mowday, R.T., Porter, L.W., \& Steers, R.M. (1982). Employee-organization linkages:The psychology of commitment, absenteeism, and turnover. New York: Academic Press.

Nurafiah, F. (2012). Pengaruh gaya kepemimpinan transformasional terhadap komitmen organisasional pada PT. Bank XYZ, Tbk, Cabang Tangerang. (Skripsi tidak dipublikasikan). Universitas Indonesia, Jakarta.

Oktorita, Y.B., Rosyid, H.F., \& Lestari, A. (2001). Hubungan antara sikap terhadap penerapan program $\mathrm{K} 3$ dengan komitmen karyawan pada perusahaan. Jurnal Psikologi. 2, 116-132.

Piccolo, R.F., \& Judge, A.T. (2004). Transformational and transactional leadership: A meta-analytic test of their reltive validity. Journal of Applied Psychology, 89.

Podsakoff, P.M., MacKenzie, S.B., \& Bommer, W.H. (1996). Transformational leader behaviors and substitutes for leadership as determinants of employee satisfaction, commitment, trust, and organizational citizenship behaviors. Journal of Management, 22 (2), 259-298. 
Porter, L.W., Steers, R. M., Mowday, R.T. \& Boulian, P.V. (1987). Organizational commitment, job satisfaction, and turnover among psychiatric technicians. Journal of applied psychology, 59(5): 603.

Purwanto, B., \& Adisubroto, D. (2001) Hubungan antara gaya kepemimpinan transformasional dan transaksional dengan komitmen terhadap organisasi. Jurnal Sosiohumanika, 14 (1).

Rahmi, M.B. (2013). Pengaruh kepemimpinan transformasional terhadap organizational citizenship behavior dan komitmen organisasional dengan mediasi kepuasan kerja (Studi pada Guru Tetap SMA Negeri di Kabupaten Lombok Timur). (Tesis tidak dipublikasikan). Universitas Udayana, Denpasar.

Shamir, B., House, R.J., \& Arthur, M.B. (1993). The motivational effects of charismatic leadership: self concept based theory. Organization Science, 4, $1-17$.
Suseno, M.N. \& Sugiyanto. (2010). Pengaruh dukungan sosial dan kepemimpinan transformasional terhadap kemampuan organisasi dengan mediator motivasi kerja. Jurnal Psikologi. Vol 37 hal 9697

Syafiq, A. (2012). Pengaruh pelatihan kepemimpinan transformasional terhadap peningkatan kualitas perilaku kepemimpinan transformasional berdasar persepsi karyawan. (Tesis tidak dipublikasikan). Fakultas Psikologi Universitas Gadjah Mada, Yogyakarta.

Tarmizi. (2008). Peningkatan pemahaman kepemimpinan transformasional melalui pelatihan dan dampaknya terhadap peningkatan komitmen organisasi dan kepuasan kerja karyawan. (Tesis tidak dipublikasikan). Universitas Gadjah Mada, Yogyakarta.

Yukl, G. (2010). Kepemimpinan dalam organisasi. Edisi Indonesia. Jakarta: Penerbit PT Indeks. 